\title{
Tibuana
}

Journal of applied Industrial Engineering-University of PGRI Adi Buana

$p$-ISSN 2622-2027

$e$-ISSN 2622-2035

\section{INFLUENCE OF CONTEXTUAL FACTORS ON INTENTION OF ENTREPRENEURSHIP}

\author{
Tegowati $^{1}$, Dian Palupi ${ }^{2}$, Widhi Ariestianti Rochdianingrum ${ }^{3}$ \\ Economic Department ${ }^{1,2,3}$ \\ Sekolah Tinggi Ilmu Ekonomi Indonesia (STIESIA) Surabaya \\ Email: tegowati@stiesia.ac.id
}

\begin{abstract}
One way to improve the competence of college graduates can be done by giving motivation to students to become entrepreneurs. In addition to improving student competency, entrepreneurship is also one of the efforts of universities to reduce the unemployment rate of college graduates. For this reason, interest in entrepreneurship among academics must be increased because it has a large contribution to the progress of a nation. This study aims to review the interests of student entrepreneurship from contextual factors.The population in this study were students in Surabaya with a sample size of 100. The sampling technique used was accidental sampling and data analysis using SEM. The results of this study are: There is a positive and significant influence of contextual factors on the interest in entrepreneurship. Based on the standardized results the parameter coefficient of 0.955 is significant at 0.001 ( $p=$ ***).
\end{abstract}

Keywords: Interest of Entrepreneurship, Contextual Factors .

\section{INTRODUCTION}

Entrepreneurship is an important role in increasing the prosperity of the people in Indonesia. As the next generation of young people, students are expected to be the initiators of entrepreneurs and creators of successful jobs in various business opportunities. In the context of entrepreneurship, the facts in the field today state that student participation in entrepreneurship is still not optimal. Therefore, guidance, training, and motivations are needed which are able to encourage students in entrepreneurship.

Increasing interest in student entrepreneurship needs to pay attention to many factors, including student background from socio-demographic factors, and contextual factors. Socio-demographic factors include gender (gender), age, field of study, parental work and experience in entrepreneurship. While contextual factors include entrepreneurship education, academic support, social support and environmental support. If in giving motivation supported by the right factors, then the motivation will be truly effective if applied in an effort to increase interest in student entrepreneurship.

In several studies that have been done before, there are several factors that can influence the interest of student entrepreneurship, including contextual factors that include entrepreneurship education, academic support, social support and environmental support, demographic factors and personality factors. In this study will analyze the influence of contextual factors consisting of entrepreneurship education, academic support, social support and environmental support for the interest of student entrepreneurship in East Java.

\section{LITERATURE REVIEW}

\subsection{Interest in Entrepreneurship}

The interest in entrepreneurship is the tendency to start new businesses (Uddin and Bose, 2012). If someone has an interest in entrepreneurship, then the person feels happy and passionate about every thing related to entrepreneurship, and shows his expression through participation in entrepreneurial activities, without any coercion from others. This entrepreneurial issue is increasingly effective, especially in the university 


\section{Tibuana \\ Journal of applied Industrial Engineering-University of PGRI Adi Buana}

p-ISSN 2622-2027

$e$-ISSN 2622-2035

environment through the application of entrepreneurship education and training on campus and practice in the field to prepare students to face the world of work. So, college graduates are expected not only to think of looking for work after the study period is over, but they can also find new opportunities and create businesses for themselves and others because they have had sufficient supplies while in college.

Ciputra (2009: 32) argues that entrepreneurship is the right solution to solve the problem of unemployment and poverty in Indonesia, because by only armed with a diploma without entrepreneurial skills, prepare yourself to queue for work because currently the supply of labor for college graduates is not comparable with job opportunities. available. Some critical factors that encourage someone to start a business according to Bygrave (1994) in Alma (2010: 9), namely: a) Personal, concerning aspects of one's personality b) Sociological, concerning problems with relations with the social environment such as family c) Environmental, concerning relationship problems with the internal environment.

The interest in entrepreneurship is the tendency to start new businesses (Uddin and Bose, 2012). Someone who is interested in entrepreneurship will feel happy and passionate about every thing related to entrepreneurship, and show his expression through participation in entrepreneurial activities, without any external force.

\subsection{Contextual Factors}

Contextual factors namely, academic support and social support are contextual factors that have a significant and positive influence on entrepreneurial intentions (Suharti and Sirine, 2011). Furthermore, Suharti and Sirine (2011) also stated that other contextual factors, namely the level of student participation in entrepreneurship training / education, and the condition of the environment (environmental support) were not proven to have an effect on students' entrepreneurial intentions.

Thus, to increase the interest in contextual student entrepreneurship is to provide knowledge and entrepreneurial education, training on entrepreneurship, university support and support for the surrounding environment.

Mopangga (2014) states that entrepreneurial interests are strongly influenced by the support of parents and families who are majority private employees and employees, public perceptions and the climate of entrepreneurial learning and academic support. Contextual factors proved to have a positive influence on the interest in entrepreneurship (Kadarsih, et al., 2013). According to Syaifudin (2016), there is a positive and significant influence on entrepreneurship education on the interest in entrepreneurship.

$\mathrm{H}$ : Contextual Factors have a positive effect on Entrepreneurial Interest

Based on the relationship between variables that have been stated, the conceptual framework in this study can be described as follows:

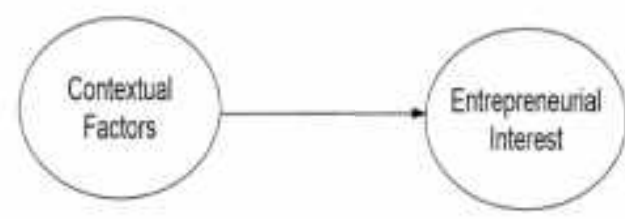

Figure 1: Research Model

\section{RESEARCH METHODOLOGY}

This research is a quantitative research because in this study the data are presented in the form of numbers and the data are analyzed statistically/ quantitatively.

The population in this study were all students in East Java who had participated in entrepreneurship courses. The number of samples determined in this study is based on the sample size proposed by Ferdinand (2014: $54)$, ie the sample is calculated by multiplying the number of indicators with multiplication ranges, ranging from the smallest to the largest multiplication range until the right sample size is found. The multiplication is as follows: $5 \mathrm{X}$ $19=95$ and rounded to 100 , because the minimum sample size for the maximum Likelihood Estimation technique is 100. So, 


\section{Tibuana}

Journal of applied Industrial Engineering-University of PGRI Adi Buana

p-ISSN 2622-2027

$e$-ISSN 2622-2035

the number of samples determined in this study is 100 .

the approach used in this study is a nonprobability sampling approach, namely accidental sampling. The data analysis technique used is SEM regression with IBM SPSS AMOS 22.0 software, because it refers to Ferdinand's statement (2014: 240) that the two analysis techniques (SPSS regression and AMOS Regression) give the same results.

\section{Test Validity and Reliability}

a. Convergent Validity Standardized loading estimate must be $\searrow 0.50$ and should ideally be 0.70 .

b. Variance Extracted AVE values equal to or above 0.50 indicate good convergence.

c. Construct Reliability

Constuct Reliability $\geq 0.70$ indicates good reliability. Reliability values of 0.60 0.70 can still be accepted provided the indicator validity in the model is good.

d. Discriminant Validity

Discriminant validity is comparing $\sqrt{ } \mathrm{AVE}$ with the correlation value between constructs.

\section{Full Model SEM Analysis}

After confirmatory analysis (validity and reliability test), the next analysis is analysis of the full structural model using SEM.

\section{SEM Assumption Test}

The assumptions that must be fulfilled in the procedure for collecting and processing data analyzed with SEM are (Ferdinand, 2014: 62):

a) Sample Size

\section{RESULTS AND DISCUSSION \\ 4.1 Full Model SEM Analysis \\ Analysis of the full structural model using SEM was carried out by entering indicators \\ that had been confirmed confirmatory.}

The minimum sample size of the Maximum Likelihood Estimation technique is 100.

b) Normality and Linearity

Data is concluded to be normally distributed if the value of the critical ratio skewness value is below the absolute price of 2.58 .

c) Outlier evaluation

Detection of multivariate outliers is done by paying attention to the value of the mahalanobis distance. Mahalanobis distance value $\chi 2(29 ; 0.001)=58.30$. If the value of an expensive distance distance> 58.30 is multivariate outliers and if the value is $<58.30$, it can be concluded that there are no outliers in the data.

1. Multicollinearityand Singularity

The very small determinant of extremely small covariance matrices gives an indication of multicollinearity and singularity problems. Create composite variables and then use the composite variables in the next analysis.

2. Evaluation of Residual Values A good model has standardized residual covariances that are smaller than 2.58.

3. Model Interpretation and Modification If a residual value is found that $\geq 2.58$ is interpreted as statistically significant at the 5\% level and it is necessary to modify the model. 


\section{Tibuana}

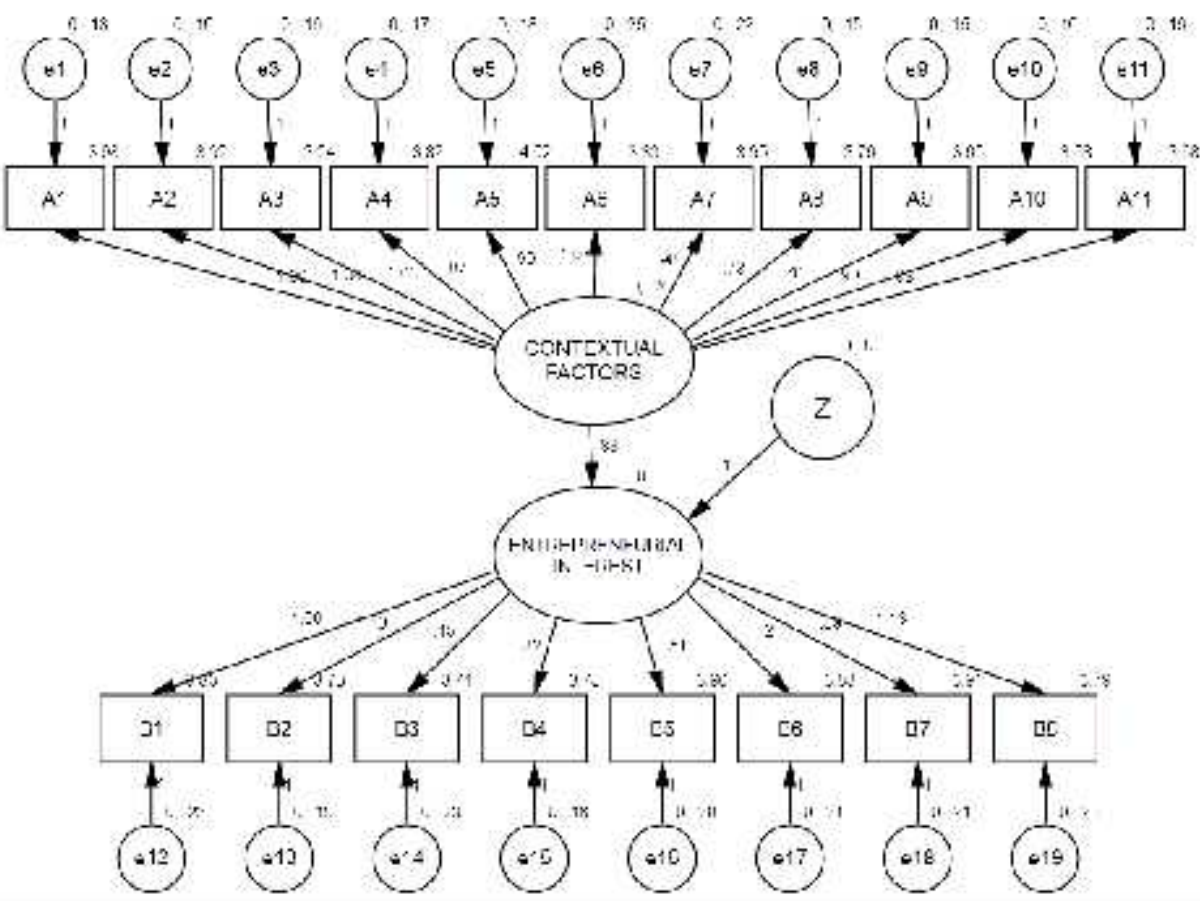

Figure 2: Full Structural Model

The output results show goodness-fit value is quite good, Chi-square value $=349,924$ probability 0,000 . The values of CMIN / DF, TLI, and CFI are all quite good. Thus the model is quite in accordance with the empirical data.

\section{Test Validity and Reliability \\ Convergent Validity}

In convergent validity calculations, the conditions that must be fulfilled are that loading factors must be significant. Because a significant loading factor may

be of low value, the standardized loading estimate must be $\geq 0.50$ and ideally it should be 0.70 . Based on the standardized loading estimate output above, all statistically significant loading factors and loading values are above 0.50 .

\section{Variance Extracted}

The value of variance extracted (AVE) $\geq 0.50$ indicates a good convergent. AVE values will be calculated for each latent construct as follows:

\section{$\Sigma$ Squared Standardized Loading:}

- Entrepreneurial Interest $=0,784^{2}+$ $0,842^{2}+0,825^{2}+0,780^{2}+0,898^{2}+0,832^{2}+$ $0,878^{2}+0,820^{2}=5,555$

- Contextual Factors $=0,861^{2}+0,922^{2}+$ $0,876^{2}+0,827^{2}+0,849^{2}+0,828^{2}+0,825^{2}+$ $0,795^{2}+0,787^{2}+0,892^{2}+0,824^{2}=7,855$

\section{Variance Extracted Calculation}

- Entrepreneurial Interest $=\frac{(5,5)^{2}}{(5,5)^{2}+2,4}=$ 0,516

- Contextual Factors $=\frac{(z, 8 ;)^{2}}{(z, 8 ;)^{2}+3.2}$

$$
=0,950
$$

The calculation of AVE above shows that all constructs have good values because they are above 0.50 . 


\section{Tibuana}

Journal of applied Industrial Engineering-University of PGRI Adi Buana

p-ISSN 2622-2027

$e$-ISSN 2622-2035

\section{Construct Reliability}

Constuct Reliability 0.70 or more shows good reliability, while the reliability of $0.60-0.70$ can still be accepted provided the indicator validity in the model is good. The calculation of constuct Reliability is as follows:

\section{Sum standardized loading:}

- Entrepreneurial Interest $=0,784+0,842$ $+0,825+0,780+0,898+0,832+0,878+$ $0,820=6.659$

- Contextual Factors $=0,861+0,922+0,876+$ $0,827+0,849+0,828+$ $0,825+0,795+0,787+0,892+0,824=9.286$

\section{- Measurement Error:}

- Entrepreneurial Interest $=0,385+0,291+$ $0,319+0,392+0,194+0,308+0,229$ $+0,328=2,446$

- Contextual Factors $=0,259+0,149+0,291+$ $0,319+0,279+0,314+0,319+0,368+0,380$ $+0,204+0,321=3.203$

\section{Calculation Reliability}

- Entrepreneurial Interest $=\frac{(6.6)^{2}}{(6.6)^{2}+2,4}=$ 0,947

$\begin{aligned}- \text { Contextual Factors } & =\frac{(y .2)^{2}}{(9.2)^{2}+3.2} \\ & =0,964\end{aligned}$

From the results of the reliability calculation, it can be seen that for all constructs the value is above the cut-off value of 0.70 . Thus it can be concluded that the indicators in this study have good reliability.

\section{Discriminant Validity}

Discriminant validity measures how far a construct is completely different from other constructs. High discriminant validity values provide evidence that a construct is unique and able to capture the measured phenomenon. The way to test it is to compare the square root value of AVE ( $\sqrt{A V E}$ ) with the correlation value between constructs. The square root value of AVE ( $\sqrt{ }$ AVE) construct as follows: 


\section{Tibuana}

Journal of applied Industrial Engineering-University of PGRI Adi Buana

p-ISSN 2622-2027

$e$-ISSN 2622-2035

environmental support for the interest in entrepreneurship. Based on the output of the parameter coefficient, it is known that the relationship of constructs of contextual factors to the interest in entrepreneurship is SIGNIFICANT at $0.001(\operatorname{sign} \mathrm{p}=* * *)$ with a standardized parameter coefficient of 0.955 . Thus it can be said that the hypothesis in this study is acceptable.

Based on the results of testing of the hypotheses that have been proposed shows that there are influences of contextual factors consisting of entrepreneurship education, academic support, social support and

\section{CONCLUSION}

Based on the theoretical basis and supported by data analysis using AMOS 22.0 software includes validity and reliability tests in the form of convergent validity, variance extracted, construct reliability, and discriminant validity, full model SEM analysis, SEM assumption test in the form of sample size, normality and linearity, outlier evaluation, multicollinearity and singularity, indicating that the data is normally distributed so that the hypothesis, discussion and conclusions are

\section{REFERENCES}

1. Alma, B. 2010. Kewirausahaan Untuk Mahasiswa dan Umum. Alfabeta. Bandung

2. Azhar, A. A. Javaid, M. Rahman and A. Hyder. 2010. Entrepreneurial Intentions Among Business Student In Pakistan. Journal of Business System, Governance and Ethics.5(2): 13-21.

3. Ciputra. 2009. Quantum Leap Entrepreneurship; Mengubah Masa Depan Bangsa dan MasaDepan Anda. Edisi 4, Elex Media Komputindo. Jakarta

4. Ferdinand, A.. Structural Equation Modeling Dalam Penelitian Manajemen Model-Model Rumit Dalam Penelitian Untuk Skripsi, Tesis dan Disertasi Doktor. Edisi 5, Badan Penerbit Universitas Diponegoro. Semarang

5. Yuliawan, E dan M Ginting. 2012. Analisis Faktor-Faktor Yang Mempengaruhi Minat Berwirausaha Mahasiswa (Studi Kasus environmental support to interest in entrepreneurship. This proves that contextual factors can fully influence the interest in entrepreneurship. That is, if you want to increase your interest in entrepreneurship in East Java, then there must be motivation or encouragement from your personal self and there is encouragement from outside, namely entrepreneurship education, academic support, social support and environmental support. The results of this study support the study of Kadarsih, et al., (2013) which states that contextual factors are proven to have a positive influence on the interest in entrepreneurship.

tested. The test results prove that contextual factors consisting of entrepreneurship education, academic support, social support and environmental support influence the interest in entrepreneurship.

\section{Thank-You Note}

In this study, we express our gratitude to the Directorate General of Higher Education for funding this research through hibah Penelitian Dosen Pemula(PDP).

Pada STMIK Mikroskil Medan). Jurnal Wira Ekonomi Mikroskil 2 (2):105-111.

6. Gurbuz, G., dan S. Aykol. 2008, Entrepreneurial Intentions Of Young Educated Public In Turkey. JournalofGlobalStrategicManagement, 4(1):47-56.

7. Indarti, N., dan R. Rostiani. 2008,Intensi Kewirausahaan Mahasiswa: Studi Perbandingan Antara Indonesia, Jepang dan Norwegia.JurnalEkonomika dan Bisnis Indonesia 23( 4).

8. Kadarsih, R., Susilaningsih, dan S. Sumaryati.2013. Faktor-Faktor Yang Mempengaruhi Minat Berwirausaha Pada Mahasiswa Program StudiPendidikan Ekonomi FKIP UNS, Jupe UNS 2 (1): 95106

9. Mopangga, H. 2014. Faktor Determinan Minat Wirausaha Mahasiswa Fakultas Ekonomi Dan Bisnis Universitas Negeri

TiBuana, Vol. 02, No. 1, 2019|43 
Gorontalo. Jurnal Trikonomika. 13(1): 7890.

10.Mulyana, M., dan R. Puspitasari. 2014. Model Struktural Minat Berwirausaha Siswa SMK Di Kota Bogor. Proceeding pada Seminar Nasional Inovasi Dan Tren (SNIT) "Peran Indonesia dalam Memberikan Apresiasi dan Kontribusi Guna Mendukung Komunitas ASEAN, Kaliabang, Indonesia. Hal 1-9. 24

11. Suharti, L., dan H. Sirine. 2011. FaktorFaktor Yang Berpengaruh Terhadap Niat Kewirausahaan (Entrepreneurial Intention) (Studi Terhadap Mahasiswa Universitas Kristen Satya Wacana, Salatiga). Jurnal Manajemen Dan Kewirausahaan.13(2): 124-134.

12.Syaifudin, A. 2016. Pengaruh Kepribadian, Lingkungan Keluarga dan Pendidikan Kewirausahaan Terhadap Minat Berwirausaha Mahasiswa Program Studi Akuntansi Universitas Negeri Yogyakarta. Skripsi. Fakultas Ekonomi Universitas Negeri Yogyakarta, Yogyakarta.
13.Tong, X. F., D. Y. K. Tong, L. C. Loy. 2011. Factors Influencing Entrepreneurial Intention Among University Students. International Journal of Social Sciences and Humanity Studies. 3(1): 487-496.

14.Uddin, Md. R., dan T. K. Bose. 2012. Determinants Of Entrepreneurial Intention Of Business Students In Bangladesh. International Journal of Business and Management.7(24): 128-137.

15.Wang, W., W. Lu, J.K. Millington. 2011. Determinants of Entrepreneurial Intention Among College Students In China and Usa. Journal of Global Entrepreneurship Research, Winter \& Spring. 1(1):35-44.

16. Yuhendri L.V. 2015. Perbedaan Minat Berwirausaha Mahasiswa Ditinjau Dari Jenis Kelamin dan Pekerjaan Orang Tua. Prosiding SNEMA 2 FE UNP padaSeminar Nasional Ekonomi Manajemen danAkuntansi (SNEMA) 2 Fakultas Ekonomi Universitas Negeri Padang. Padang, Indonesia. Hal. 244-249. 